\title{
STUDIES ON SPECTROSCOPIC AND CRYSTAL STRUCTURE OF DICHLORO CARBONYL DIPYRIDINE TRIPHENYLARSINE RUTHENIUM(II) COMPLEX
}

\author{
M. Gowri ${ }^{1}$, T. Srinivasan ${ }^{2}$, D. Velmurugan ${ }^{2}$ \\ ${ }^{1}$ Department of Chemistry, Avinashilingam University for Women, Coimbatore - 641 043, Tamilnadu, India \\ E-mail: sriadit.gowrisuresh@gmail.com \\ ${ }^{2}$ CAS in Crystallography and Biophysics, University of Madras, Guindy Campus, Chennai - 600 025, Tamilnadu, \\ India \\ E-mail: srini771@gmail.com,shirai2011@gmail.com
}

Received February, 7, 2015

The title complex $\left[\mathrm{Ru}(\mathrm{Cl})_{2}(\mathrm{CO})(\mathrm{py})_{2}\left(\mathrm{AsPh}_{3}\right)\right]$, was synthesized and characterized. The molecular structure and crystal structures are determined by X-ray crystallography. The dihedral angle between the two cis-pyridine rings is $73.3(2)^{\circ}$, which shows that they are almost orthogonal to each other. The molecular structure is stabilized by inter-molecular and intra-molecular $\mathrm{C}-\mathrm{H}$... Cl interactions. The molecular structure is further stabilized by interactions between the aromatic rings.

DOI: $10.15372 / J S C 20150822$

K e y w o r d s: Ru(II) complex, triphenyl arsine, pyridine, chloride, carbonyl complex, crystal structure.

\section{INTRODUCTION}

Due to the potential as versatile catalysts for organic synthesis and polymer production, ruthenium complexes have witnessed a spectacular development. Several series of organometallic complexes of ruthenium have been prepared and extensively used in variety of chemical transformations like oxidation [ 1,2$]$, hydration [ 3,4$]$, hydrogenation [ 5-7], isomerization [ 8-10], decarbonylation [11], epoxidation [12-14], Diels-Alder reaction [15, 16], cross coupling reaction [17] and other related catalytic processes. Dipyridyl Ru(II) complexes have been used in anti-tumor treatment as alternatives to cis-platin. The octahedral geometry of $\mathrm{Ru}(\mathrm{II})$ allows for reactivity and binding that cannot be achieved by the square-planar Pt(II) cis-platin system [18, 19]. Metal carbonyls are useful in organic synthesis and as catalysts or catalyst precursors in homogeneous catalysis. Pyridine is widely used as a ligand in coordination chemistry. When a pyridine ligand is part of a metal complex, it can be replaced by a stronger Lewis base. This property has the advantage in the catalysis of polymerization [20,21] and hydrogenation reactions [22]. The pyridine ligand replaced during the reaction is restored after its completion like triphenyl phosphine/triphenyl arsine.

Based on the above discussions, we have undertaken spectroscopic and X-ray structural studies of a novel $\mathrm{Ru}(\mathrm{II})$ complex $\left[\mathrm{Ru}(\mathrm{Cl})_{2}(\mathrm{CO})(\mathrm{py})_{2}\left(\mathrm{AsPh}_{3}\right)\right]$.

\section{EXPERIMENTAL}

Synthesis. A mixture of $\left[\mathrm{Ru}(\mathrm{H})(\mathrm{Cl})(\mathrm{CO})(\mathrm{py})\left(\mathrm{AsPh}_{3}\right)_{2}\right](860 \mathrm{mg}, 1 \mathrm{mmol})[23]$ and $(\mathrm{Z})-4-(((2-$ hydroxy phenyl)imino)methylene)-3-methyl-1-phenyl-1H-pyrazol-5-one $(290 \mathrm{mg}, 1 \mathrm{mmole})\left[\mathrm{H}_{2} \mathrm{~L}\right]$ [24] was taken in a round bottomed flask in the solution of equal volume mixture of ethyl acetate and

(C) Gowri M., Srinivasan T., Velmurugan D., 2015 
chloroform and refluxed over a water bath for about $5 \mathrm{~h}$. The reaction results in two types of products. They were separated and subjected to various spectroscopic analyses.

This paper describes the spectroscopic and structural details of the brown colored crystals obtained apart from the green tiny crystals as major product.

Elemental analyses. The elemental analyses were obtained from SAIF, Cochin, Kerala. Found for $\left[\mathrm{Ru}(\mathrm{Cl})_{2}(\mathrm{CO})(\mathrm{py})_{2}\left(\mathrm{AsPh}_{3}\right)\right](\%)$ : C 53.56, H 3.63, N 4.16. Calculated (\%): C 52.37, H 3.76, N 4.21.

FTIR spectrum. The coordination mode of the central metal atom with ligands can be well understood from the absorption peaks of FTIR spectrum of the resulted complex and also on comparison with that of the ligands. The characteristic frequency of aromatic $\mathrm{C}-\mathrm{H}$ stretching $\left(3050 \mathrm{~cm}^{-1}\right)$ and $\mathrm{C}-\mathrm{H}$ bending $\left(734 \mathrm{~cm}^{-1}\right)$ are found in the expected regions. The presence of strong absorption peaks at $692 \mathrm{~cm}^{-1}, 1069 \mathrm{~cm}^{-1}, 1483 \mathrm{~cm}^{-1}$ confirms the presence of triphenyl arsine [25] which is coordinated to the central ruthenium through the As atom. The presence of terminally coordinated carbon monoxide as ligand is evident from the presence of a strong sharp peak at $1954 \mathrm{~cm}^{-1}$ [23 ]. Comparison of the IR spectrum of the complex with that of the pyridine indicates shifting of a strong absorption peak at $1578 \mathrm{~cm}^{-1}$ to $1601 \mathrm{~cm}^{-1}$, in accordance with the coordination of pyridine to ruthenium through the nitrogen atom [26].

X-ray diffraction. The title complex crystallizes in monoclinic with the space group of $C 2 / c$ with cell parameters $a=32.4259(6) \AA, b=10.0558(2) \AA, c=22.8155(4) \AA, \beta=133.738(1)^{\circ}, Z=8, M_{r}=$ $=664.40$ and $V=5375.0(2) \AA^{3}$. The structure was solved by direct methods using SHELXS-97 and refined by full-matrix least squares method using SHELXL-97 programs [27]. The final $R$ factor value is 0.0296 with the GOOF value of 1.036 for 6642 independent reflections.

X-ray diffraction intensity data was collected on a Bruker AXS SMART APEXII single crystal $\mathrm{X}$-ray diffractometer equipped with graphite monochromated $\operatorname{MoK}_{\alpha}(\lambda=0.7103 \AA)$ radiation source and CCD detector. Crystals were cut to suitable size and mounted on a glass fibre using cyanoacrylate adhesive. The unit cell parameters were determined from 36 frames measured $\left(0.5^{\circ} \varphi\right.$-scan $)$ from three different crystallographic zones and using the method of difference vectors. The intensity data were collected with an average four-fold redundancy per reflection and optimum resolution $(0.75 \AA)$. The intensity data collection, frames integration, Lorentz and polarization correction and decay correction were done using SAINT-NT (version 7.06a) software. Empirical absorption correction (multi-scan) was performed using SADABS (Bruker, 2008) program [ 28 ].

In the title complex, $\left[\mathrm{Ru}(\mathrm{Cl})_{2}(\mathrm{CO})(\mathrm{py})_{2}\left(\mathrm{AsPh}_{3}\right)\right]$, the dihedral angle between the two pyridine rings $((\mathrm{N} 1 / \mathrm{C} 1-\mathrm{C} 5)$ and $(\mathrm{N} 2 / \mathrm{C} 6-\mathrm{C} 10))$ is $73.3(2)^{\circ}$, which shows that they are almost orthogonal to each other. The angles around As1 atom $\left(\mathrm{C} 11-\mathrm{As} 1-\mathrm{C} 23=105.88(11)^{\circ}, \mathrm{C} 11-\mathrm{As} 1-\mathrm{C} 17=\right.$ $=102.28(10)^{\circ}$ and $\left.\mathrm{C} 23-\mathrm{As} 1-\mathrm{C} 17=97.18(11)^{\circ}\right)$ deviates from the ideal tetrahedral values which may be a steric interaction between benzene rings and $\mathrm{Ru}$ atom. The molecular structure is stabilized by $\mathrm{C} 24-\mathrm{H} 24 \ldots \mathrm{Cl} 2\left(\mathrm{H} \ldots \mathrm{Cl}=2.70\right.$ and the angle $\left.\mathrm{C} 24-\mathrm{H} 24 \ldots \mathrm{Cl} 2=133^{\circ}\right)$ intra-molecular halogen interaction, which results in pseudo six membered ring structure. The crystal packing features intermolecular $\mathrm{C} 13-\mathrm{H} 13 \ldots \mathrm{Cl1}$ halogen bond interactions with the distance of $\mathrm{H} \ldots \mathrm{Cl}=2.862(2) \AA$ and the angle $\mathrm{C} 13-\mathrm{H} 13 \ldots \mathrm{Cl} 1=145^{\circ}$ (Symmetry code: $-x+1 / 2,-y+1 / 2+1,-z$ ). The molecular structure is further stabilized by $\mathrm{Cg} 1 \ldots \mathrm{Cg} 2$ interactions with the distance of 3.7127(19) $\AA$, where $\mathrm{Cg} 1$ is the center of gravity of $(\mathrm{N} 1 / \mathrm{C} 1-\mathrm{C} 5)$ and $\mathrm{Cg} 2$ is the center of the gravity of $(\mathrm{C} 11-\mathrm{C} 16)$. The molecular structure of the title complex, the crystal packing of the title compound viewed down $c$ axis showing the hydrogen bonds are given in Figs. 1 and 2 respectively.

Fig. 1. The molecular structure of the title complex, showing displacement ellipsoids drawn at the $30 \%$ probability level. $\mathrm{H}$ atoms are removed for structure clarity

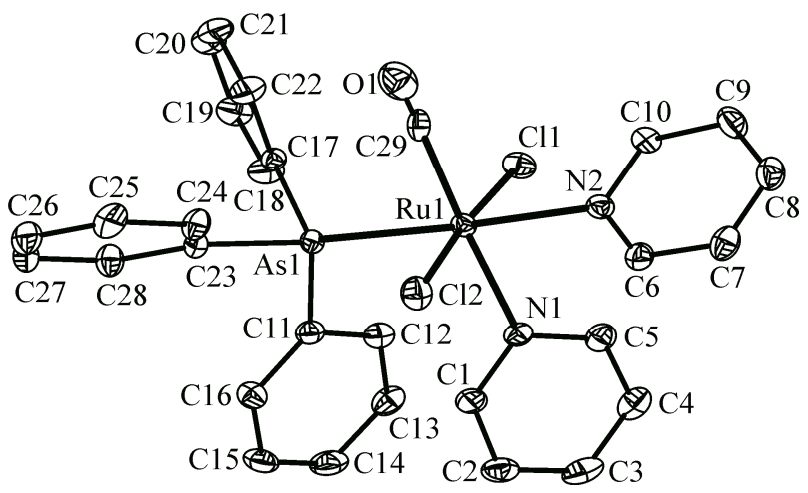




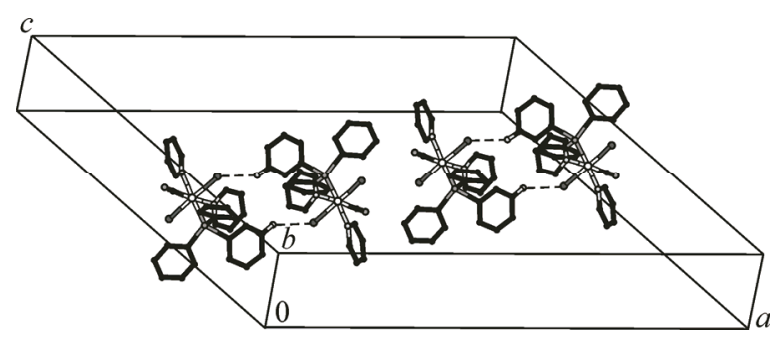

Fig. 2. The crystal packing of the title compound viewed down $c$ axis, showing the hydrogen bonds; $\mathrm{H}$ atoms not involved in $\mathrm{H}$ bonds have been excluded for clarity.

Dotted line shows hydrogen bonds $\mathrm{C}(13)-\mathrm{H}(13) \ldots \mathrm{Cl}(1)$

The main details of the X-ray diffraction of the title complex $\left[\mathrm{Ru}(\mathrm{Cl})_{2}(\mathrm{CO})(\mathrm{py})_{2}(\mathrm{AsPh} 3)\right]$ are given in Table 1. The crystallographic data has been deposited in Cambridge Crystallographic Data Centre (CCDC No. 894858) deposit@ccdc.cam.ac.uk. These data can be obtained free of charge via www.ccdc.cam.ac.uk/data request/cif, or emailing data request@ccdc.cam.ac.uk. or by contacting The Cambridge Crystallographic Data Centre, 12 Union Road, Cambridge CB2 IEZ, UK.

\section{CONCLUSION}

This research article describes the spectroscopic and X-ray determination of the new novel crystal which is obtained as byproduct in the synthesis of ruthenium(II) complex which is coordinated to dibasic tridentate Schiff base ligand. During the reaction, it is expected that certain ligands like pyridine, chloride, triphenyl arsine and hydride gets detached from the starting precursor complex. These detached ligands from the precursor complex, reacts with the same precursor complex and results in the formation of the titled complex and this conversion may be expected to be catalyzed by the main product obtained in the same reaction. Synthesis of various metal complexes and its evaluation of catalytic activities are ongoing project in our laboratory. The results will be published in due course.

\begin{tabular}{l} 
Crystal data and structure refine \\
\hline Empirical formula \\
Formula weight \\
Temperature, $\mathrm{K}$ \\
Wavelength, $\AA$ \\
Crystal system; space group \\
Unit cell dimensions $a, b, c, \AA ; \beta$, deg. \\
Volume, $\AA^{3}$ \\
$Z$; Calculated density, g/cm ${ }^{3}$ \\
Absorption coefficient, $\mathrm{mm}^{-1}$ \\
$F(000)$ \\
Crystal size, mm \\
$\theta$ range for datacollection, deg. \\
Limiting indices \\
Reflections collected / unique \\
Completeness to $\theta=28.32 \%$ \\
Absorption correction \\
Refinement method \\
Data / restraints / parameters \\
Goodness-of-fit on $F^{2}$ \\
Final $R$ indices $[I>2 \sigma(I)]$ \\
$R$ indices (all data) \\
Largest diff. peak and hole, e/ $\AA^{3}$ \\
CCDC No.
\end{tabular}

C29 H25 As Cl2 N2 O Ru

664.40

293(2)

0.71073

Monoclinic; $C 2 / c$

$32.4259(6), 10.0558(2), 22.8155(4) ; 133.738(10)$

$5375.0(2)$

$8 ; 1.642$

2.030

2656

$0.20 \times 0.20 \times 0.20$

1.74 to 28.32

$$
\begin{gathered}
-42 \leq h \leq 42,-13 \leq k \leq 12,-29 \leq l \leq 30 \\
24815 / 6642[R(\text { int })=0.0251] \\
99.3 \\
\text { None }
\end{gathered}
$$

Full-matrix least-squares on $F^{2}$

6642 / 0 / 325

1.036

$R_{1}=0.0296, w R_{2}=0.0713$

$R_{1}=0.0404, w R_{2}=0.0762$

0.652 and -0.581

894858 


\section{REFERENCES}

1. Nakamura Y., Egami H., Matsumoto K., Uchida T., Kalsuki T. et al. // Tetrahedron. - 2007. - 63, N 28. - P. $6383-6387$.

2. Yamaguchi K., Won Kim J., He J., Mizuno N. et al. // J. Catal. - 2009. - 268. - P. 349.

3. Shukla R.S., Bhatt S.D., Thorat R.B., Jasra R.V. et al. // Appl. Catal. - 2005. - 294A. - P. 111 - 118.

4. Alvarer P., Bassetti M., Gimeno J., Mancini G. et al. // Tetrahedron Lett. - 2001. - 42. - P. $8467-8470$.

5. Dupau P., Hay A.E., Bruneau C., Dixneauf P.H. et al. // Tetrahedron: Asymmetry. - 2001. - 12. - P. 863 867.

6. Daley C.J.A., Wiles J.A., Bergens S.H. et al. // Inorg. Chim. Acta. - 2006. - 359. - P. $2760-2770$.

7. Haque F.N., Lough A.J., Morris R.H. et al. // Inorg. Chim. Acta. - 2008. - 361. - P. 3149 - 3158.

8. Picquet M., Bruneau C., Dixneuf P.H. et al. // Chem. Commun. - 1997. - P. $1201-1202$.

9. Van der Drift R.C., Vailati M., Bouwman E., Drent E. et al. // J. Mol. Catal. Chem. - 2000. - 159A. - P. 163 177.

10. Krompiec S., Pigulla M., Bieg T., Szczepankiewicz W., Kunik N., Krompiec M., Kubichi M. et al. // J. Mol. Catal. A: Chem. - 2002. - 189. - P. $169-185$.

11. Jenner G., Nahmed E.M., Leismann H. et al. // J. Organomet. Chem. - 1990. - 387. - P. 315 - 321.

12. Barf G.A., Hoek D., Sheldon R.A. et al. // Tetrahedron. - 1996. - 52. - P. $1297-1303$.

13. De Souza V.R., Nunes G.S., Rocha R.C., Toma H.E. et al. // Inorg. Chim. Acta. - 2003. - 348. - P. 50 - 56.

14. Valodkar V.B., Tembe G.L., Ravindranathan M., Rama H.S. et al. // React. Funct. Polym. - 2003. - 56. - P. $1-15$.

15. Davenport A.J., Davies D.L., Faweett J., Russell D.R. et al. // Dalton Trans. - 2004. - P. 1481 - 1492.

16. Diaz-Alvarez A.E., Crochet P., Zablocka M., Cadierno V., Vendier L., Gimeno J., Majoral J.P. et al. // Polyhedron. - 2007. - 26. - P. 933 - 940.

17. Planas J., Hampel F., Gladysz J.A. et al. // Chem. Eur. J. - 2005. - 11. - P. 1402 - 1416.

18. Mazumder U.K., Gupta M., Karkim S.S., Bhattacharya S., Rathinasamy S., Sivakumar T. // Bioorg. Med. Chem. - 2005. - 13. - P. 5766 - 5773.

19. O'Connor M.B., Killard A.J., O'Kennedy R., Forster R.J., Smyth M.R.J. et al. // Inorg. Biochem. - 2006. - 100. - P. 1252 - 1259.

20. Bamford C.H., Tipper C.F.H. et al. Comprehensive Chemical Kinetics: Non-Radical Polymerisation. - Amsterdam: Elsevier, 1980.

21. Hopper A.V. Recent Developments in Polymer Research. - Nova Science Publisher, 2007.

22. Crabtree R. et al. // Acc. Chem. Res. - 1979. - 12, N 9. - P. 331 - 337.

23. Gopinathan S., Unny I.R., Deshpande S.S., Gopinathan C. et al. // Ind. J. Chem. - 1986. - 25A. - P. 1015 1022.

24. Gowri M., Krishnan C.J. et al. // Int. J. Appl. Biol. Pharm. Technol. - 2012. - 3. - P. 327 - 337.

25. Das A.K., Peng S.M., Bhattacharya S. et al. // J. Chem Soc., Dalton Trans. - 2000. - P. $181-184$.

26. Gill N.S., Nuttall R.H., Scnife D.E., Sharp D.W.A. et al. // J. Inorg. Nucl. Chem. - 1961. - 18. - P. 79 - 87.

27. Sheldrick G.M. // Acta Crystallogr. - 2008. - 64A. - P. 112 - 122.

28. Bruker. APEX2, SAINT and SADABS. - Madison, Wisconsin, USA: AXS Inc., 2008. 